\title{
KNOWLEDGE OUTFLOWS FROM FOREIGN SUBSIDIARIES AND THE TENSION BETWEEN KNOWLEDGE CREATION AND KNOWLEDGE PROTECTION: EVIDENCE FROM THE SEMICONDUCTOR INDUSTRY
}

\author{
Alessandra Perri \\ Ca' Foscari University, Department of Management \\ Ulf Andersson \\ Copenhagen Business School, Department of Strategic Management and Globalization
}

\begin{abstract}
This paper analyzes the MNC subsidiaries' trade-off between the need for knowledge creation and the need for knowledge protection, and relates it to the extent of knowledge outflows generated within the host location. Combining research in International Business with Social Theory, we build a conceptual framework suggesting that subsidiaries that extensively draw on external knowledge sources are also more likely to generate knowledge outflows to local firms. We argue that this may be explained by the subsidiaries' willingness to build the trust that facilitates the establishment of reciprocal knowledge linkages. However, when the value of the subsidiary's knowledge stock is very high, the need for knowledge protection restrains reciprocity mechanisms in knowledge exchanges, thus reducing the extent of knowledge outflows to the host location. This study contributes to the literature on the firm-level antecedents of FDI-mediated local knowledge outflows, as well as to the broad IB literature on the relationship between subsidiaries and their host regions. The implications for managers and policy-makers are also discussed.
\end{abstract}

Keywords: local knowledge outflows, FDI, knowledge creation, knowledge protection 


\section{INTRODUCTION}

A widely investigated topic in the field of international business (IB) is the globalization of the innovative activities of Multinational Corporations (MNCs), particularly in high-technology sectors (Phene \& Almeida, 2008). Since the pioneering works that attributed the very existence of MNCs to the failure of the international market for technology (Buckley \& Casson, 1976), a growing body of literature has started to look at MNCs as geographically distributed networks of innovation, whose main ability is to assimilate, create and integrate knowledge on a global basis (Kogut \& Zander, 1993; Birkinshaw, 1997; Frost, Birkinshaw \& Ensign, 2002).

An important consequence of MNCs' international distribution of innovation resides in the phenomenon of the knowledge flows to the host-location. Indeed, beyond absorbing knowledge from local sources of expertise, MNCs' foreign subsidiaries also diffuse - either intentionally or unintentionally - some of their knowledge to domestic firms (Almeida, 1996), through the process of local interaction (Haskel, Pereira \& Slaughter, 2007). Much literature has analysed the direction, the scope, the channels and the antecedents of such knowledge flows (Teece, 1977; RodriguezClare, 1996; Song, Almeida \& Wu, 2003; Feinberg \& Majumdar, 2001; Giroud \& Scott-Kennel, 2009).

Overall, theory predicts that the higher the technological distance between the MNC's home and host economy, the higher the potential for FDI knowledge outflows and local learning (Findlay, 1978). Yet, in order for this potential to materialize, host-country firms need to enjoy a sufficient level of absorptive capacity, which may enable them to effectively adopt and integrate such pieces of knowledge (Glass \& Saggi, 1998). Several other macro-level factors have been found to play a role in this process. In fact, literature has demonstrated that in order to predict the level of local knowledge outflows from FDI, it is important to account for the differences in terms of hostcountries' trade policy (Kokko, Zejan \& Tansini, 2001), intellectual property rights regimes (Javorcik, 2004; Zhao, 2006), local competition (Wang \& Blomstrom, 1992; Perri, Andersson, Nell \& Santangelo, 2013) and the sectoral structure of FDI (Crespo \& Fontoura, 2007). Despite this 
substantial strand of research on FDI local knowledge outflows, an accurate analysis of the extant literature still reveals some gaps.

In the first place, while there is plenty of analysis regarding the country-level and industry-level determinants of this phenomenon, the influence that the firm itself (and, in particular, its subsidiaries) may exert on the patterns of local knowledge outflows remains an under investigated topic. Notable exceptions have tried to account for the role of the MNCs' investing motive (Chung, 2001; Driffield \& Love, 2007), of the relationships with the MNC internal network (Zhao, 2006; Driffield, Love \& Menghinello, 2010), and of the type of activity realized abroad by foreign facilities (Branstetter, 2006; Marin \& Bell, 2006). Despite these contributions, research has failed to look at how the subsidiary's strategy, in terms of the management of its knowledge assets, affects the extent of the knowledge that flows to domestic firms. However, this issue is relevant since it is by now recognized that subsidiaries can actively manage their knowledge resources within their local context (Birkinshaw \& Hood, 1998; Cantwell \& Mudambi, 2005), thus generating heterogeneous patterns of interaction with the local knowledge network and, hence, different levels of knowledge outflows.

In addition, IB and strategy literature has looked at the knowledge exchange relationships between subsidiaries and domestic firms from two different perspectives. Traditional research on subsidiary innovation (Almeida \& Phene, 2004; Phene \& Almeida, 2008), mandate (Birkinshaw \& Hood, 1998; Cantwell \& Mudambi, 2005) and embeddedness (Andersson, Forsgren \& Holm, 2002; 2007) has highlighted the role of the local firms as a source of valuable resources and knowledge. On the other hand, literature on the knowledge protection strategies of multinational firms (Alcacer \& Chung, 2007; De Faria \& Sofka, 2010; Shaver \& Flyer, 2000; Zhao, 2006) has pointed to the threats, in terms of knowledge spillover, arising from the contact with the local context. An integrated analysis of the double role the interaction with domestic firms plays for a subsidiary's competitiveness is still missing. 
In order to account for these gaps, in this paper, we theoretically analyze how the opportunities and challenges subsidiaries face in the local knowledge network influence the patterns of knowledge outflows they generate to the host location. We conceptualize the mechanism that drives the subsidiaries' management of their knowledge assets as the tension between knowledge creation and knowledge protection. A subsidiary's knowledge creation is highly dependent on its ability to leverage external resources (Almeida \& Phene, 2004). Building on social network theory (Hansen, 1999; Dyer \& Hatch, 2006), we suggest that the access to such resources is facilitated by the involvement in reciprocal exchange relationships (Håkansson \& Snehota, 1989; Johanson \& Mattsson, 1992; Kachra \& White, 2008), which consequently boost the knowledge outflows to local firms. However, such relationships - through which knowledge flow bidirectionally - may also be detrimental for subsidiaries' competitive standing in the foreign location, especially when their knowledge is highly valuable. In this latter case, subsidiaries might be driven to strengthen their knowledge protection strategies when interacting with the local environment, thus reducing the level of knowledge outflows.

The conceptual framework developed in this paper proposes that the differences in patterns of local knowledge outflows generated by MNCs' foreign subsidiaries may be explained by accounting for the trade-off between knowledge creation and knowledge protection they face within their host location. We analyze the need for knowledge creation by looking at subsidiaries' external focus in knowledge sourcing, which allows us to speculate on the consequences, in terms of local knowledge outflows, of subsidiaries' ability to absorb knowledge from external sources. Additionally, we focus on subsidiaries' knowledge value as one condition that may activate the need for knowledge protection.

While our main objective in this paper is to offer conceptual understanding of how the tension between knowledge creation and knowledge protection may influence the extent to which subsidiaries generate knowledge outflows to the host-location, in the last section of the manuscript we also carry out an exploratory analysis aimed at providing preliminary empirical insights on our 
framework's validity. Using patent citation data relating to a set of US subsidiaries of foreign MNCs, our empirical results suggest that an external focus in knowledge sourcing tends to be associated with higher levels of knowledge outflows. However, in the presence of a high value of subsidiaries' knowledge stock, the extent of local knowledge outflows appears to be narrowed. Our conceptual framework suggests that one possible explanation for this phenomenon is that, in order to source external knowledge, subsidiaries may build on reciprocity mechanisms that foster knowledge outflows. However, they also tend to increasingly protect their highly valuable knowledge assets. Under this condition, they limit reciprocity behaviors in knowledge exchanges and reduce the extent of local knowledge outflows.

Our study contributes to the literature on FDI knowledge outflows, by accounting for the double role host locations play for subsidiaries' competitiveness. Previous research has analyzed either subsidiaries' knowledge exchange dynamics (Almeida, 1996; Singh, 2007) or MNCs' strategies to prevent knowledge leakage (Alcacer \& Chung, 2007). No study has elaborated on the simultaneous effects that the need for knowledge creation and the need for knowledge protection exert on the phenomenon of local knowledge outflows. We believe that this focus will set the stage for a more comprehensive understanding of how subsidiaries find a balance between such conflicting forces, and shed more light on the subsidiary-level antecedents of FDI local knowledge outflows. In addition, by highlighting some of the social mechanisms underpinning FDI-mediated local knowledge outflows, our conceptual framework provides a more socially enriched description of this phenomenon.

The rest of the paper is organized as follows. In the next section, we review the existing research on subsidiaries' knowledge flows and knowledge management. We then elaborate on the "trade-off" between knowledge creation and knowledge protection, and develop hypotheses. Finally, we present the exploratory analyses we have conducted on our sample of subsidiaries, and discuss the resulting empirical insights. 


\section{LITERATURE REVIEW}

\subsection{Knowledge flows and knowledge spillovers: an overview of existing research}

IB theory has highlighted that the localization of FDI generates positive externalities for hostcountry firms. This finding has fostered the development of a substantial strand of literature on FDImediated spillovers to host-countries (for a review, see Görg \& Greenaway, 2003). Spillovers from FDI may take different forms. Beyond the ability to boost local employment and to pull in large capital inflows, the embedding of multinational operations may result in knowledge outflows, which span MNCs affiliates' boundaries through several channels. Established literature suggests that knowledge flows from MNCs to host-country firms derive from the technological assets generated by parent companies (Caves, 1974), which can be transferred to subsidiaries located abroad (Dunning, 1981). When this transfer takes place, the contact between MNCs' subsidiaries and the local firms may produce local knowledge outflows, allowing host-country firms to access MNCs' technology (Haskel et al., 2007).

Traditional theory predicts that MNCs belonging to countries, or to industries within a country, that are more advanced than host country organizations, are more likely to generate knowledge-based spillovers (Findlay, 1978). Yet, host country firms are required to have a minimum level of absorptive capacity to internalize such knowledge (Glass \& Saggi, 1998). Empirical literature has also found that the patterns of the FDI knowledge outflows are governed by relevant crosscountries, as well as cross-industries differences (Narula \& Dunning, 2000; Singh, 2007).

In a departure from these "macro-level" analyses of the antecedents of FDI-mediated knowledge spillovers, in recent years, scholars have recognized that also the firm heterogeneity may play a role in this phenomenon. As an example, Chung (2001) and Driffield \& Love (2007) find that the firms' investing motive influences the FDI knowledge spillover effect. In his research on Japanese investors in the United States, also Branstetter (2006) focuses on firm-level characteristics, and shows that FDI are more likely to generate knowledge outflows to American firms when they take the form of greenfield production facilities and distribution centers, since they are supposed to 
embody the parent firms' technological superiority. Conversely, Driffield et al. (2010) suggest that subsidiaries that receive more of the parent firm's technology do not share knowledge with local firms. Finally, Marin \& Bell (2006) propose the "active subsidiary model", and show that subsidiaries' own technological activity is an important determinant of the knowledge outflows to host country firms.

While being very important in shedding some lights on the firm-specific determinants of the FDImediated local knowledge diffusion, these studies seem to focus on the structural characteristics of subsidiaries (e.g. type of facility, type of local activity), thus overlooking the potential impact of subsidiaries' strategy. One reason for this gap may be that traditional literature has considered subsidiaries as passive actors of both the MNC and the host-country networks (Marin \& Bell, 2006; Alcacer \& Chung, 2007; De Faria \& Sofka, 2010), whose aim is just to implement the tasks assigned by the headquarters, with scarce - if any - autonomy in terms of strategy-making. However, recent IB literature (Ensign, Birkinshaw \& Frost, 2000; Holm \& Pedersen, 2000) has highlighted the importance of examining firms' strategic behaviour also "at the level of the subsidiary, rather than the level of the corporate group as a whole" (Cantwell \& Mudambi, 2005). In fact, MNCs' subsidiaries have been found to be increasingly active in terms of the management of their knowledge assets (Mudambi \& Navarra, 2004; Cantwell \& Mudambi, 2005; Marin \& Bell, 2006). In order to gain a more comprehensive understanding of the firm-level determinants of the local knowledge outflows generated by FDI, a closer look at how subsidiaries manage their knowledge needs in the host location is therefore required.

A second under-examined factor in the literature on FDI spillover refers to the role of network ties between foreign and domestic firms (Eapen, 2012). Network ties are important because they often originate repeated and intense interaction among actors (Hansen, 1999). Such interaction is crucial in facilitating the flow of knowledge between a source and a recipient (Kotabe, Martin, \& Domoto, 2003). In fact, especially when the contacts between network actors are regular, interaction generates opportunities to be exposed to each other's pieces of knowledge (Peteraf and Shanley, 
1997), and allows gaining more fine-grained information on how to make a productive use of such knowledge (Kotabe et al., 2003). Regular contacts and cooperative experience also allow for the development of trust, which in turns improves actors' willingness to exchange useful information (Andrews \& Delahay, 2000) and reduces the need to verify the validity of shared knowledge (Zaheer, McEvily \& Perrone, 1998). While IB literature has already recognized the relevance of network ties between foreign and domestic firms in fostering FDI local knowledge outflows (Driffield, Munday \& Roberts, 2002; Ghauri and Buckley, 2006; Spencer, 2008), the contingencies under which such ties are really effective in channeling knowledge from foreign to domestic firms remain under-investigated. In fact, in the context of knowledge outflows from FDI, the interaction between foreign and local firms must take place despite the potential competitive relationship between them, i.e. despite the fact that the knowledge shared with local firms may represent a competitive cost for foreign subsidiaries (Eapen, 2012). Under the influence of such competitive considerations, foreign firms need to have strong incentives to commit effort and resources to the development of ties with local counterparts (Hansen, 1999; Kotabe et al., 2003; Sako, 1996). In the absence of such incentives, or when the competitive risks arising from the contact with local firms are very high, foreign subsidiaries might be unwilling to commit to the development of strong ties with domestic firms, thus reducing the intensity of the interaction and, hence, the extent of local knowledge outflows. In other words, the likelihood of FDI local knowledge outflows is dependent on foreign subsidiaries' willingness to interact with domestic firms. To support this statement, the following analysis of opportunities and challenges emerging from the host location allows exploring some of the contingencies under which foreign subsidiaries display heterogeneous incentives to commit to social ties with local firms.

\subsection{Local firms in IB literature: opportunities and challenges for subsidiaries' knowledge management}


Traditional IB research has looked at the local context as the source of valuable resources, to which subsidiaries should gain access in order to be successful within their internal and external networks. Almeida \& Phene (2004) show that the host-country's technological diversity increases foreign subsidiaries' knowledge creation capability. Similarly, Phene \& Almeida (2008) demonstrate that the knowledge assimilated from host-country firms is positively associated with both the scale and the quality of a subsidiary innovation. Also Birkinshaw \& Hood (1998) and Cantwell \& Mudambi (2005) elaborate on the importance of the local context for subsidiaries' acquisition of competencecreating mandate. Finally, Andersson et al. $(2002$, 2007) suggest that the embeddedness with local firms increases the subsidiary performance, as well as its importance and power within the MNC internal network. Based on this logic, the host location is a source of opportunities, and the interaction with local firms is desirable and beneficial.

A different perspective on the role of host country for MNCs arises from research on firms' heterogeneity and agglomeration dynamics. Alcacer \& Chung (2007) and Shaver \& Flyer (2000) have suggested that the host country can be a threat for MNCs' competitive position, and have analyzed the strategies that leading MNCs use to manage and protect their knowledge from the risk of local knowledge outflows. Their works show that MNCs assess their location choices based on an accurate evaluation of the net (inward vs. outward) knowledge spillover. As a consequence, technologically advanced MNCs avoid agglomerating with highly concentrated clusters of related industrial activities, in order to protect their knowledge from external appropriation. Also Zhao (2006) considers the risks of conducting R\&D in countries with weak Intellectual Property Rights, and finds that MNCs seek to internalize their technology by using it more extensively within the MNCs' network. Finally, recent empirical evidence suggests that, in presence of very high local competition, subsidiaries reduce the investment into their vertical local linkages to limit the risk of local horizontal spillover (Perri et al., 2013).

Although apparently contrasting, the above-mentioned perspectives are complementary, and can provide a clearer understanding of a subsidiary's needs, in terms of the management of its 
knowledge assets, only if considered jointly. Support for this statement is provided by the recent work by De Faria \& Sofka (2010), who find that subsidiaries adapt their knowledge protection strategies to both their own characteristics and host-country challenges and opportunities. We extend this stream of research by analyzing how the way subsidiaries manage such challenges and opportunities affects the extent of knowledge outflows they generate within the local context, by shaping subsidiaries' willingness to commit resources to the interaction with the network of domestic firms.

We posit that subsidiaries are subject to two different stimuli emerging from the host location: a need for knowledge creation, which arises from the willingness to benefit from the learning opportunities embedded in the external environment, and a need for knowledge protection, which derives from the urge to safeguard their competitive knowledge from the risk of local dissemination. The tension between these two needs will affect subsidiaries' choices, in terms of knowledge assets' management and interaction with local firms, thus ultimately influencing the extent of knowledge outflows generated in the host location. This framework is consistent with recent knowledge-based research (Arikan, 2009) highlighting that firms have two knowledge imperatives: to 1) "secure access to all the knowledge it needs to prolong its value creation activities", thus sourcing knowledge inputs from external networks to which it belongs; and to 2) "exploit all the bodies of knowledge it possesses to the fullest", thus appropriating of all the rents its knowledge generates.

In the following section, we elaborate on the concept of the tension between knowledge creation and knowledge protection, and employ social network literature to show how subsidiaries' choices in terms of commitment to local interaction may affect the extent of knowledge outflows to the host location. 


\section{THEORY DEVELOPMENT}

\subsection{Local knowledge outflows and the need for knowledge creation: subsidiaries' external focus in knowledge sourcing}

Knowledge creation is a complex activity, which firms can hardly carry out in isolation. Relying just on the resources residing within a firm's organizational boundaries may not always be sufficient to renew a firm's knowledge endowment. In order to feed their knowledge production process, firms need to acquire knowledge from external sources and recombine them with internal resources (von Hippel, 1988; Lundvall, 1992; Veugelers, 1997; Chesbrough. 2004; Laursen \& Salter, 2006).

Local firms are an important source of knowledge for foreign subsidiaries. In a departure from the traditional view of the host-country as a mere option to create new markets or to obtain cheap resources, the "learning-oriented FDI" perspective has increasingly provided evidence about the knowledge opportunities offered by host regions (Cantwell, 1989). Literature has demonstrated that sector-specific knowledge develops in geographically concentrated areas (Marshall, 1920; Porter, 1990), and that countries follow different patterns of industrial specialization (Patel \& Pavitt, 1991). Subsidiaries that access local sources of expertise absorb knowledge that may be highly beneficial, since it's often complementary, or at least different (hence, non-redundant), to that of the MNC (Singh, 2008). An abundance of studies demonstrates that subsidiaries extensively source knowledge from host regions (Almeida, 1996; Frost, 2001; Singh; 2007), and that this allows them to gain competence-creating mandates and power (Cantwell, 1989, 1995; Cantwell \& Janne, 1999), and to increase the quantity and the quality of their innovation (Almeida \& Phene, 2004; Phene \& Almeida, 2008).

However, acquiring knowledge from the external environment is not an immediate consequence of a subsidiary's localization in a foreign country. Localized knowledge flows through "the establishment of interfirm (and interpersonal) linkages between firms in a region" (Almeida \& Phene, 2004, p. 849). As previously stated, in order to exchange resources and share unique 
knowledge, firms must involve in tight and repeated interactions that stimulate the creation of social networks and trust (Rogers \& Larsen, 1984). When this happens, firms learn to benefit from each other, since they develop common cognitive models and collaborative attitudes; in addition, they may engage in processes of joint problem solving and information sharing, useful for their innovative activities (Gulati, 1995).

In the specific case of foreign firms, the access to localized sources of expertise may require them to build a reputation for cooperation, which allows subsidiaries that share their technology with local firms to become embedded in the domestic knowledge network. Local firms are more likely to share their own resources and information with foreign counterparts if they expect to obtain valuable knowledge in return (Schrader, 1991; Kachra \& White, 2008). Conversely, if they do not perceive collaborative inclinations on the part of foreign firms, they will hardly engage in such benevolent behavior (von Hippel, 1987). Social network literature suggests that network structures and common third-party ties are crucial to activate social monitoring mechanisms (Coleman, 1988; Reagans \& McEvily, 2003). Network participants are able to recognize those actors who refuse to act cooperatively. Hence, network actors' opportunistic inclination compromises their ability to interact with the network in the future (Reagans \& McEvily, 2003). In the context of FDI, foreign subsidiaries wishing to gain access to local knowledge and information might need to signal cooperation towards the network of domestic firms, as a way of mitigating the latters' expectations of opportunistic behavior (Polidoro, Ahuja \& Mitchell, 2011). This will allow subsidiaries to gain a facilitated access to domestic firms' information. As a consequence, subsidiary managers might wish to involve into reciprocal relationships with host-country firms and accept to disclose some of their knowledge, if they expect to gain a greater local integration that facilitates the acquisition of relevant knowledge. Social theory has demonstrated that this reciprocity mechanism is vital to the exchange of resources (Gouldner, 1960; Williamson, 1993): as a case in point, Saxenian (1994) reports the importance of knowledge sharing between firms for the dynamism and the success of the Silicon Valley region. Building on these findings, Business Network literature has highlighted the 
advantages firms can reap from stable and reciprocal relationships (Håkansson \& Snehota, 1989; Johanson \& Mattsson, 1992). Similarly, Kachra \& White (2008) elaborate on the role of the selfinterested "process of giving and getting" in the transfer of know-how between scientists. In sum, firms may deliberately engage in knowledge trading if the cost of giving away pieces of their knowledge is offset when the receiver returns the favor (Schrader, 1991).

We posit that subsidiaries that are interested in gaining access to the external sources of knowledge, and - as a consequence - have a need for knowledge creation, might find useful to demonstrate their willingness to reciprocate, thus accepting the leakage of some of their knowledge within the host location. The need for knowledge creation represents a compelling incentive for foreign subsidiaries to commit time and effort in the interaction with local firms, which will drive them to neglect the competitive implications of local knowledge outflows. Hence, under a need for knowledge creation, when subsidiaries aim to absorb local knowledge, they will invest resources in the development of ties with local firms, thus creating the conditions for effective knowledge outflows to the local network. We define the external focus in knowledge sourcing as a subsidiary's ability to absorb knowledge from the external environment, and to use this knowledge for further innovation. We expect that an external focus in knowledge sourcing is associated with reciprocity mechanisms, since subsidiaries that absorb knowledge from the outside are also expected to contribute to the knowledge network in which they are embedded, thus generating a higher extent of knowledge outflows:

Hypothesis 1: There is a positive relationship between a subsidiary's external focus in knowledge sourcing and the extent of knowledge outflows to local firms.

\subsection{Local knowledge outflows and the need for knowledge protection: the value of} subsidiaries' knowledge

A well-established stream of literature suggests that innovation in multinational subsidiaries is a peculiar process, since they are simultaneously embedded in two different knowledge contexts: (1) 
the internal multinational firm network, composed of the headquarters and other sister units; (2) the external set of host country firms (Almeida \& Phene, 2004). The opportunity to absorb knowledge from both these networks is nontrivial for subsidiaries' innovative output and creative processes. Traditional IB literature suggests that MNCs are highly effective in managing and leveraging their knowledge resources within their internationally distributed network, which makes their knowledge endowment especially rich and advanced (Bartlett \& Ghoshal, 1989; Kogut \& Zander, 1993; Hedlund, 1994; Birkinshaw, 1997; Frost et al., 2002). Subsidiaries that are able to draw on MNCs' knowledge assets and to exploit the geographically distributed learning opportunities they are exposed to develop highly valuable knowledge. In turn, their ability to compete locally is highly reliant on such "superior" knowledge. Moreover, they become extremely attractive for local actors (Håkansson \& Nobel, 2001), especially if the latter are strictly domestic, and hence do not have the chance to overcome the local search as multi-location firms do.

Resource-based theory suggests that, in order to serve as a means to pursue the firm's competitive advantage, resources must have some particular characteristics: among others, they must be rare and difficult to imitate (Barney, 1991; Dyer \& Singh, 1998). In fact, when they diffuse to competitors and become replicable, they lose their strategic value.

According to the Knowledge-based Theory of the Firm (Grant, 1996), knowledge assets are a firm's most important resources and the primary sources of their rents. As a consequence, "firms have every reason to prevent others from accessing a valuable body of knowledge they possess so that the knowledge remains rare and a source of competitive advantage" (Arikan, 2009; p. 662). Based on this line of reasoning, we expect that subsidiaries will not be willing to share their valuable knowledge with local firms. Subsidiaries' incentive to protect their knowledge from external appropriation increases with the value of such knowledge. In fact, the higher the knowledge value, the higher the loss associated with its diffusion. We conclude that increasing levels of knowledge value activate subsidiaries' need for knowledge protection. In turn, a higher knowledge protection will result in a lower extent of subsidiaries' knowledge outflows to local firms: 
Hypothesis 2: There is a negative relationship between the value of a subsidiary's knowledge and the extent of knowledge outflows to local firms.

\subsection{Local knowledge outflows and the tension between knowledge creation and knowledge protection}

In presence of a need for knowledge creation, subsidiaries will seek to invest into reciprocal exchange relationships to the aim of absorbing beneficial knowledge from the external environment. Conversely, under a need for knowledge protection, subsidiaries will try to restrain their knowledge outflows to the host location. How will subsidiaries manage the simultaneous presence of these knowledge needs? Based on our framework, to answer this question it is important to explore how such conflicting objectives may affect foreign firms' motivation to commit resources to knowledge exchange relationships with local firms. In fact, in order for these relationships to be effective in channelling knowledge, relationship actors must invest time and effort in their development, fostering their quality and strength.

As previously argued, a counteracting pressure to subsidiaries' willingness to invest into relational ties refers to the competitive implications of sharing knowledge with rivals (Eapen, 2012). When the value of a subsidiary knowledge is very high, the loss arising from its external dissemination is accordingly high. In presence of such a competitive risk, subsidiaries' motivation to invest in the development of ties is inherently reduced, and so will be the effectiveness of ties to act as knowledge channels. Hence, the prospect of bearing a high competitive cost - i.e. the dissemination of highly valuable knowledge to local rivals - represents a key constraint to subsidiaries' incentive to commit resources to the maintenance of close interactions with local firms.

In accordance with this reasoning, we suggest that, although subsidiaries may accept some knowledge leakage if they expect to gain access to local sources of expertise and technology, such "tolerant" attitude can be moderated by competitive considerations. When subsidiaries are the repository of valuable knowledge, and hence are subject to the need for knowledge protection, they 
might be expected to look at the reciprocity mechanisms stemming from an external focus in knowledge sourcing with reluctance. In fact, the local diffusion of their knowledge could be highly detrimental for their competitive advantage. In addition, whereas reciprocal relationships with local firms activate privileged channels for resource sharing, through which subsidiaries may access to local knowledge, subsidiaries do not know in advance what is the actual value of such knowledge. Under the condition of a highly valuable knowledge base, the reciprocal interaction with local firms would drive subsidiaries to trade knowledge of guaranteed high value against knowledge of uncertain value.

Literature suggests that - although the source of relevant resources - knowledge-based interactions can be risky for a firm's knowledge appropriation, and may endanger its competitive standing (Arikan, 2009). We suggest that - being aware of this risk - subsidiaries that possess valuable knowledge will be less willing to commit to interactive, reciprocal relationships with local firms. Compared to subsidiaries that do not enjoy highly competitive knowledge, they have much more to lose than to learn from intense and repeated interaction with local firms. Therefore, the value of a subsidiary's knowledge acts as a moderator of the reciprocity in knowledge exchanges arising from an external focus in knowledge sourcing.

Previous literature has highlighted that the technological heterogeneity of multinational firms affects their location choices (Shaver \& Flyer, 2000, Alcacer \& Chung, 2007). While lagging MNCs tend to agglomerate in clusters of related industrial activities, where the inward spillover (i.e., the knowledge inflows) is higher than the knowledge outflows - leading MNCs avoid highly concentrated locations, where they have much to lose and very little to learn. We argue that a similar mechanism applies to subsidiaries, and to their knowledge exchange strategies in the host regions. Specifically, we propose that subsidiaries that possess highly valuable knowledge are less willing to engage in reciprocal relationships (that might act as a channel for knowledge outflows) with local firms, since their need for knowledge protection is higher than their need for knowledge creation. In fact, as they already enjoy high levels of knowledge value, they expect to spill over the 
local knowledge network much more than they can learn from it. In such cases, even in presence of an external focus in knowledge sourcing, subsidiaries will seek to moderate reciprocal knowledge exchanges and increase their protective barriers, thus reducing the extent of knowledge that diffuses in the host location.

Summarizing this reasoning, we hypothesize that - in presence of an external focus in knowledge sourcing - the value of a subsidiary's knowledge emphasizes the need for knowledge protection and moderates the effects of reciprocity in knowledge exchanges:

Hypothesis 3: The value of a subsidiary's knowledge stock negatively moderates the relationship between the external focus in knowledge sourcing and the extent of knowledge outflows to local firms.

\section{EMPIRICAL ANALYSIS}

\subsection{Data}

In this last section of the paper, we carry out an exploratory analysis whose aim is to offer preliminary empirical insights on our framework's validity. Our empirical strategy is to use patent citation data to measure the knowledge outflows generated by multinational subsidiaries in their host locations, and to develop measures that proxy our constructs of subsidiaries' focus in knowledge sourcing and the value of subsidiaries' knowledge stock. While this does not allow capturing the knowledge creation and protection processes that we discussed in our conceptual framework, it will provide some preliminary evidence on how different degrees of external focus in knowledge sourcing and of knowledge value might affect the generation of knowledge outflows from foreign to local firms. In fact, established literature suggests that - whereas the information contained within a patent does not allow pointing out the underlying mechanisms that enable knowledge flows - it offers the opportunity to evaluate the outcomes of such mechanisms (Almeida \& Phene, 2004; Phene \& Almeida, 2008; Song et al., 2003). 
The advantages of using patent citation data to analyze the knowledge outflow phenomenon stem from the information they provide. Thanks to this information, patents allow to pinpoint the locus of the innovative activity, the organization to which the patent is assigned, and the temporal and technological features of the invention. In addition, patent documents report a list of citations to other patents, which is useful to identify the technological antecedents to the particular innovation (Almeida, 1996).

We conduct our empirical analysis on a sample of US subsidiaries of European and Asian firms from the semiconductor industry. This is an appropriate empirical setting since it is one of the most technology intensive industries. Hence, profiting from external knowledge inflows while preventing the outflow of proprietary technology to competitors is a central issue for agents affiliated to this industry.

To create our sample, we followed the procedure used by Almeida \& Phene (2004) \& Phene and Almeida (2008). We considered 10 European and Asian semiconductor MNCs among the sales leaders in year 2005. This list of firms was constructed using information from Gartner Dataquest and Osiris. For this set of MNCs, we identified U.S. subsidiaries engaged in innovation between 1990 and 2005. Our final sample is composed of 29 subsidiaries, observed over a 16-years period: hence, the unit of analysis is a subsidiary-year. The total number of observation in our sample should be 29 (the number of subsidiaries) multiplied by 16 (the number of years of observation). However, not all subsidiaries were observed throughout the whole period, since some of them only began patenting after 1990. Moreover, due to the difficulties of gathering non-patent data for the very first years of our period of analysis, we had to drop some firm-year observations due to missing values. As a result, the actual size of our sample was 299. Patent data were obtained from the U.S.P.T.O. and the NBER patent citation data file (Hall, Jaffe \& Trajtenberg, 2001). Firm level data were obtained from Osiris. 


\subsection{Measures}

\subsubsection{Dependent variable}

Knowledge Outflows to Local Firms As most of the studies about knowledge spillovers and knowledge flows, the dependent variable used in this paper stems from the geographic information contained on citations listed by a U.S. subsidiary's patent. Specifically, to capture the knowledge outflows from MNCs' subsidiaries to local firms, our dependent variable is defined as the number of (forward) citations made to a subsidiary's patent portfolio $^{1}$ in year $t$ by the universe of localinvented patents applied for in year $\mathrm{t}$.

In order to select the local citations relevant to the purpose of the analysis, the characterization of the correct sub-national geographic unit of analysis is crucial. Following recent trends in IB literature (Tallman \& Phene, 2007; Zhao \& Islam, 2007), in this study, we chose to use a more finegrained option than that of the State, opting for the "Metropolitan Statistical Area" (MSA), as identified by the United States Office of Management and Budget ${ }^{2}$ (OMB). This choice is justified by the observation that many of the relevant U.S. semiconductor technology clusters span more than one state (e.g., New York - New Jersey - Connecticut tri-state area), and some states host more than one cluster (e.g., California).

\subsubsection{Independent variables}

External Focus in Knowledge Sourcing It is difficult to directly observe the focus of firms' knowledge sourcing. Therefore, in order to proxy a subsidiary's external focus in knowledge

\footnotetext{
${ }^{1}$ To identify a subsidiary's patent portfolio, we analyzed the patent assignee name (typically, the name of the MNC, like Sony or Samsung), and the address of the inventor (which had to be located within the boundaries of the Metropolitan Statistical Area where the subsidiary itself was established). The patent application date of successfully registered patents was used as the year of innovation. Only semiconductor patents were chosen as part of the subsidiary's patent portfolio, based on Derwent's technological classification. Hence, we selected only patents belonging to the first four Derwent patent classes included in the section "Semiconductors and Electronic Circuitry": U11 (semiconductor materials and processes), U12 (discrete devices), U13 (integrated circuits) and U14 (memories, film and hybrid circuits).

${ }^{2}$ According to the U.S. Census Bureau, a Metropolitan Statistical Area is "a geographic entity, defined by the Federal $O M B$ for use by Federal statistical agencies, based on the concept of a core area with a large population nucleus, plus adjacent communities having a high degree of economic and social integration with that core".
} 
sourcing, we will measure the outcomes of such focus, as represented by citation data. Following Frost (2001), we assume that the attitude of subsidiaries to innovate by building directly upon different sources of knowledge may be inferred through the analysis of the pattern of citations referenced by a particular subsidiary patent ${ }^{3}$. Along with this reasoning, we assume that the greater the number of citations (referenced by a subsidiary patent) to patents generated by local organizations, the greater the subsidiary external focus in knowledge sourcing. Hence, following Almeida \& Phene $(2004)^{4}$, we calculate the subsidiary external focus in knowledge sourcing as the total number of (backward) citations a subsidiary's patent portfolio has referenced to patents that (a) were assigned to a firm other than the MNC, and (b) whose inventor was located in the same MSA as the subsidiary, in the three years prior to year $\mathrm{t}^{5}$.

Value of a Subsidiary's Knowledge Stock Most of the studies that use patent data proxy the value of innovation with the number of forward citations a patent receives (Trajtenberg, 1990; Gittelman \& Kogut, 2003; Singh, 2008). When patents are extensively cited, it means that the knowledge they embody has been used to realize several further innovations. Therefore, it is supposed to be relevant and productive. Hall et al. (2005) find that firms' patent citations are significantly correlated with their market value. As a consequence, highly cited patents should correspond to relevant technological innovations (Gittelman \& Kogut, 2003).

To build our measure of the value of a subsidiary's knowledge stock, we embrace this perspective and consider the average number of citations that a subsidiary's patent portfolio has received up to

\footnotetext{
${ }^{3}$ A similar framework has been used by Almeida \& Phene (2004), to measure the "subsidiary focus" in knowledge sourcing: according to the authors, a large numbers of self-citations reflect "an inward looking focus and an emphasis on exploitation", while a small number of self-cites suggests "an external orientation and a focus on exploration" (Almeida \& Phene, 2004). Similarly, Phene \& Almeida (2008) in their study about the role of knowledge assimilation and subsidiaries capabilities for subsidiaries' innovative processes suggest that "cited patents identify the technological antecedents of the innovation, and reflect the knowledge assimilated to create innovation" (Phene \& Almeida, 2008): therefore, analysing cited patents, we can infer what are the knowledge bodies on which subsidiaries have build to create new knowledge.

${ }^{4}$ In this paper, the authors measure the "subsidiary focus" in knowledge sourcing as the total number of self backward citation the subsidiary's patent portfolio has referenced to patents assigned to the subsidiary itself, in year t- 1 .

${ }^{5}$ This is because we expect a lag between the subsidiary's external focus in knowledge sourcing and our dependent variable.
} 
year $\mathrm{t}-1^{6}$ (total number of citation/scale of the subsidiary's patent portfolio). We excluded from this count the self-citations from the MNC (both from the subsidiary itself, and from any other tie of the MNC's internal network), in order to have an objective evaluation of the value that external agents recognize to the subsidiary's knowledge (Phene \& Almeida, 2008). This provides us with a measure of the value of a subsidiary's knowledge stock in terms of “average citations received on a perpatent basis for the subsidiary patent portfolio" (Phene \& Almeida, 2008; p.908).

\subsubsection{Controls}

A series of firm, patent portfolio and locational characteristics have been applied as control variables in our model.

First, since we expect that the number of citations a subsidiary receives depends on the number of patents it owns, we controlled for the size of a subsidiary's patent portfolio in year t, a count-based measure of the patents a subsidiary has successfully applied for up to year t (Portfolio Size).

The age of the patent portfolio is a variable needed to control for heterogeneity in the "citedness" of different foreign subsidiaries, which is driven by differences in the age distribution of their patent stocks (Branstetter, 2006). Jaffe et al. (2000) have found that the knowledge contained in patents needs time to diffuse. Therefore, patent citations tend to increase over time at the beginning of the cited patent lifetime, and to decrease over longer periods, as the innovations they represent become dated $^{7}$ (Branstetter, 2006). To account for this effect, for each year and each subsidiary, we included an index (Portfolio Age) calculated as the number of patents, in a subsidiary's patent portfolio, that are at this peak “citing age”, divided by the residual number of a subsidiary's patents.

Moreover, to assure that differences in the extent of knowledge outflows are not driven by the degree of local integration of the foreign subsidiaries, we added a measure that accounts for the

\footnotetext{
${ }^{6}$ Also in this case, we expect a lag between the quality of innovation and our dependent variable.

${ }^{7}$ Empirical evidence shows that a patent usually receives its highest amount of citations 4-6 years after its granting (Branstetter, 2006). However, since the semiconductor industry is a fast-changing technological environment, and semiconductor products have a duration of a product life cycle of 5 year on average (Almeida and Phene, 2008), we considered the peak age of semiconductor patents as being comprised between 3-5 years.
} 
number of years in which the subsidiary has been located in the U.S. For foreign subsidiaries to be integrated within the host-location, both formal and informal linkages must be created and nourished. These linkages constitute an easy channel through which knowledge may flow to hostcountry firms. However, for these channels to develop, it takes a long time (Criscuolo, Narula \& Verspagen, 2002), since subsidiaries must embed in the local context. Controlling for the subsidiary age, we seek to isolate this effect from the ones that are the main objects of this research. We build this variable as the number of years between year $t$ and the year of the subsidiary's first patent application $^{8}$ (Subsidiary Age). Note that this variable, however, does not completely define subsidiary embeddedness since, as previous literature has suggested, several other factors (e.g., personal networking, trust, mutual adaptation, breadth of interaction) contribute to explain the extent to which subsidiaries become integrated within the host-location (Uzzi, 1996, 1997; Gulati, 1998; Andersson et al., 2002).

Research shows the existence of different barriers that may impede effective knowledge sharing ${ }^{9}$. For instance, it has been argued that knowledge is power (Mudambi \& Navarra, 2004). Hence, the risk of losing knowledge-driven power can be a critical element that hinders actors' knowledge sharing intentions. Michailova \& Husted (2003) refer to this phenomenon as "knowledge-sharing hostility", described as a sort of inclination not to share knowledge. Previous literature has suggested that this inclination is likely to differ across cultures (Chow, Deng \& Ho, 2000; Michailova \& Hutchings, 2006). More specifically, some evidence exists that Eastern managers tend to be less willing to share knowledge than their Western counterparts (Chow et al., 2000). To control for this factor ${ }^{10}$, we include a dummy variable (Home Region) that takes the value of 1 if the subsidiaries' home country is located in European countries, and 0 if it is located in Asia.

\footnotetext{
${ }^{8}$ Unless we had more precise information on subsidiary establishment.

${ }^{9}$ We thank an anonymous reviewer for highlighting this point.

${ }^{10}$ Note that knowledge sharing hostility is a very complex human phenomenon. Hence, it is driven by other factors that cannot be fully captured by a "home region" dummy variable.
} 
Subsidiaries that are part of strongly research-oriented organizations are more likely to obtain future citations because of the higher visibility and reputation of their multinational network. To account for this effect, we include a measure of the MNC's R\&D intensity ( $R \& D$ Intensity) calculated as the total $R \& D$ expenses as a percentage of sales in year $\mathrm{t}-1$.

We also control for the number of inventors from other units of the MNC involved in the subsidiaries' innovative activities. Involving a large number of scientists from other units into a subsidiary's innovative activity may be a signal of the prominence of the technological project as well as of the size of the budget associated with it. To account for this effect, we include a measure (Team Size) calculated as the average number of inventors from other units of the MNC on a perpatent basis for the subsidiary patent portfolio, in year t-1.

The headquarters' technological assets have been traditionally considered as a major determinant of the local knowledge spillovers (Caves, 1974). To control for such HQ-level characteristic, we introduce a measure (Headquarters' Knowledge Stock) given by the total number of semiconductor patents applied for by the headquarters (whose inventor location is the MNC's home country), up to year $\mathrm{t}-1$.

Localized knowledge flows are more likely to happen in clusters of concentrated technological activities (Jaffe \& Trajtenberg, 1998). To account for this, we also included a measure (Cluster Importance) given by the total number of semiconductor patents applied for by inventors located in the focal MSA in year $\mathrm{t}$.

The patterns of knowledge spillovers in a specific region can be influenced by the underlying distribution of the technological activities within that area (Jaffe, Trajtenberg and Hendersen, 1993). Therefore, to control for the technological "closeness" between the subsidiary and its local context, we introduced in our model a measure of "technological proximity" 11 (Technological Proximity) between the firm and the local knowledge network (Jaffe, 1986).

\footnotetext{
${ }^{11}$ We build this measure following Jaffe (1986).
} 
Since our research analyses subsidiaries over a number of years, we added year dummies in our model to account for possible effects of serial correlation. We also included a set of dummies to control for host-regions unobserved heterogeneity.

\subsection{Methods}

The first econometric concern about empirical analyses involving patents and patent citations refers to the count nature of the dependent variable (Hausman, Hall \& Griliches, 1984). Literature suggests dealing with this type of data by using a Poisson model. However, such model is based on the assumption of no heterogeneity in the sample. In fact, unobserved heterogeneity may lead to a case of "over-dispersion", thus generating underestimation of standard errors and an inflation of significance levels.

When performing a Poisson estimation on our full model, the results showed a high and significant value of chi-square (chi-square $=2924.12$, with a p-value of 0.0000 ), which signals the presence of over-dispersion, and advises against the use of the Poisson specification. We dealt with this problem by using an econometric model whose design corrects for the presence of over-dispersion: the negative binomial regression model, developed by Hausman et al. (1984). As suggested by a Hausman test, we used the random effects specification.

\section{FINDINGS AND DISCUSSION}

Table 1 presents the descriptive statistics and bivariate correlations among all variables included in our model.

Table 1 about here

The high value of the correlation coefficients between the External Focus in Knowledge Sourcing and the Portfolio Size (0.641) as well as between the Subsidiary Age and Knowledge Value (0.653) requires attention, and will be object of further investigation in our sensitivity analysis. Potential 
problems of multicollinearity could also emerge from the inclusion of our interaction variable. To account for this issue, we followed the standard procedure (Aitken \& West, 1991) and meancentered the interacting terms to reduce collinearity.

The results of our negative binomial models with random effects are presented in Table 2 .

Table 2 about here

We first test a baseline model (Model 1) including all our controls variables. The results point to the importance of the Portfolio Size for the local knowledge outflows phenomenon, and confirm the prediction that subsidiaries with a larger stock of patented innovations generate more local knowledge outflows. Also the dummy variable Home Region has a positive and slightly significant effect on our dependent variable, suggesting that subsidiaries belonging to European MNCs contribute more to the local knowledge network, compared to Asian firms. This seems to be consistent with previous literature (Chow et al., 2000).

Model 2 presents our findings on the effect of subsidiaries' External Focus in Knowledge Sourcing on the extent of knowledge outflows to local firms. The coefficient of our External Focus in Knowledge Sourcing variable is positive $(+0.028)$ and highly significant $(p<0.01)$, and the Wald statistic increases from 196.54 to 234.11 . This result shows that the higher is the extent of knowledge a subsidiary absorbs from external sources, the higher will be its contribution to the local knowledge network, in terms of knowledge outflows. This finding seems to provide some empirical support to Hypothesis 1 that, in order to gain and maintain the access to the host knowledge base, the subsidiary will need to reciprocate the knowledge acquired externally, accepting the leakage of some of its proprietary technology.

Model 3 tries to explore the effects of the subsidiaries' need for knowledge protection. Our findings highlight a negative $(-0.251)$ and significant $(p<0.01)$ coefficient of the Knowledge Value term. This can be interpreted as preliminary evidence on our Hypothesis 2, according to which 
subsidiaries that are able to produce highly valuable knowledge are less likely to share it with their host location, since they find it crucial to maintain the control on it. As a consequence, they generate lower levels of knowledge outflows to local firms.

Model 4 presents the results of the full model. The inclusion of the interaction term between a subsidiary's External Focus in Knowledge Sourcing and the Value of its knowledge leads to an increase in the overall fit of the model, with the Wald statistic at 243.14. While the signs of the interacting terms remain unchanged, the interacting coefficient turns out to be negative (-0.019) and significant $(p<0.01)$, suggesting some support for our Hypothesis 3. In presence of high Knowledge Value, the relationship between the External Focus in Knowledge Sourcing and the extent of Knowledge Outflows to local firms is negatively moderated. Interpreting this finding in the light of our conceptual framework, we might infer that when subsidiaries' knowledge is strongly valuable, subsidiaries seek to enforce their knowledge protection strategies, thus restraining the reciprocity mechanisms associated with the need for knowledge creation. This leads to a lower extent of local knowledge outflows. In fact, we expect that in presence of high Knowledge Value, the need for knowledge protection is more urgent than the need for knowledge creation.

\subsection{Sensitivity Analyses and Robustness Checks}

Due to the high correlation between some of our variables, we performed several sensitivity analyses to ensure the robustness of our results.

We first dealt with the high value of the correlation coefficient between the External Focus in Knowledge Sourcing and the Portfolio Size (0.641). We ran our full model regressions without the Portfolio Size variable: our results did not change, and the External Focus in Knowledge Sourcing maintained its sign and significance. Also the correlation between the Subsidiary Age and Knowledge Value (0.653) is very high. We dropped the Subsidiary Age variable and performed our full model: also in this case, all results maintained their signs and overall significance. 
We conducted further robustness checks on our models. First, we tried alternative formulations of our External Focus in Knowledge Sourcing variable. The original measure we used is based on the citations a subsidiary makes to local patents in the three years prior to year $\mathrm{t}^{12}$. In order to test the robustness of this variable, we ran our models with alternative specifications of the External Focus in Knowledge Sourcing, by measuring it over a single-year period (t-1) and over a five-year period. Our findings maintain their signs, as well as their overall significance.

Second, we wanted to account for the use of the MSA as the locations' boundary within which local knowledge outflows take place. Although administrative boundaries do not necessarily define the shape of the locations where firms exchange knowledge, we use the State boundaries as an alternative definition of "host-region". Also in this case, the regression results maintain the expected signs and significance.

\subsection{Conclusions}

Our study investigates the trade-off between the need for knowledge creation and the need for knowledge protection, and how it affects the extent of knowledge outflows subsidiaries generate within their host regions. Building on Social Theory, we propose a conceptual framework that offers a set of hypotheses linking subsidiaries knowledge strategies to the extent of local knowledge outflows. In addition, we use patent data to carry out an exploratory analysis aiming at providing initial evidence on our conceptual model. Statistical wisdom suggests some support for our hypotheses. In fact, our study shows that subsidiaries that source more from the external knowledge network are also more likely to contribute to it. We suggest that this phenomenon is partially driven by the mechanism of reciprocity in knowledge exchanges. In fact, a possible interpretation of this result relies in the willingness to gain access to foreign pockets of expertise and complementary knowledge, which may drive subsidiaries to tolerate the leakage of part of their own knowledge to

\footnotetext{
12 This focus on the past is meant to proxy how the subsidiary's local knowledge sourcing behavior affects its subsequent knowledge outflows to the host location. Specifically, we built the variable over a three-years period in order to make sure that the subsidiary's knowledge sourcing was a structured behavior, rather than just a mere occurrence.
} 
local firms. Based on our conceptual framework, we infer this behavior is probably justified by the intention to build up the trust needed to facilitate local knowledge inflows. However, as the value of subsidiaries' knowledge increases, the level of knowledge outflows diminishes, suggesting that subsidiaries tend to protect their assets from external appropriation more, when the competitive value of such assets is very high. Interestingly, our results also show that the interaction between the value of a subsidiary knowledge and its external focus in knowledge sourcing is negatively associated with the level of local knowledge outflows. This could be interpreted in the light of our theoretical reasoning, which suggests that the presence of high knowledge quality lowers the effects of reciprocity in knowledge exchanges. In sum, based on our conceptual framework, we believe that such findings might be explained in the light of a tension between the need for knowledge creation and the need for knowledge protection: when the value of a subsidiary's knowledge is very high, the pressure to protect its assets is much more urgent than the need to build reciprocal knowledge linkages that could foster the creation of new knowledge. Specifically, subsidiaries with high knowledge value that source external knowledge seek to moderate mechanisms of knowledge reciprocity, and to protect their knowledge more extensively. This is due to the greater potential danger associated with the dissemination of their knowledge in the host location. Our conceptual framework is therefore consistent with a recent theoretical study on inter-firm knowledge exchanges within a cluster, claiming that "knowledge interactions are plagued by opportunism and appropriability problems. Solutions to these problems lie in the development of trust and norms of cooperation within the cluster. Yet competitive challenges make the development of cooperative norms highly difficult while at the same time creating numerous reasons to break them once they are established" (Arikan, 2009; p. 672).

The study offers two main contributions. In the first place, it adds to the literature on the firm-level antecedents of FDI-mediated knowledge diffusion (Chung, 2001; Branstetter, 2006; Marin \& Bell, 2006; Driffield \& Love, 2007), which so far has focused on the structural profile of the MNCs and the subsidiaries, while leaving aside the issue of the subsidiary's knowledge strategies. Building on 
recent insights on the active role of subsidiaries in the generation (Cantwell \& Mudambi, 2005; Phene \& Almeida, 2008) and protection (De Faria \& Sofka, 2010) of knowledge in MNCs, we investigate how a subsidiary's management of its knowledge assets influences the extent of knowledge outflows generated locally. Furthermore, by including into our conceptual framework the role of the social mechanisms underlying the process of knowledge diffusion from MNCs' foreign subsidiaries to local firms, we offer a more socialized view of the FDI-mediated knowledge outflows phenomenon. This is in line with recent theoretical research highlighting the pervasive role social norms play in FDI spillover related issues (Eapen, 2012).

More broadly, this paper contributes to general IB literature on the relationship between subsidiaries and their host regions. Overcoming traditional perspectives that have mainly looked at the foreign location either as an opportunity or as a threat for MNC subsidiaries' competitiveness, we show that both the roles are possible, if we explicitly account for the subsidiaries' needs in term of knowledge creation and knowledge protection.

\subsection{Limitations}

Though this paper provides interesting insights on the firm-level antecedents of FDI local knowledge outflows, the study bears some limitations. First, our empirical analysis is limited to the US subsidiaries of leading multinational firms in the semiconductor industry. This sample selection procedure - which was driven by data availability - may imply a bias toward more experienced, large firms. Hence, the findings should be interpreted accordingly. It is possible that the mechanisms of knowledge protection and knowledge creation we infer from the empirical results are partially driven by these firms' accumulated capability in managing their knowledge assets, while could not hold for smaller and less experienced firms. Moreover, their ability to absorb knowledge from the local environment could be influenced by their international standing and reputation of leading firms. More in general, the restriction of this study to a single industry, and single host country, generates mixed implications. On the one hand, this setting limits unobserved 
heterogeneity. On the other hand, it raises concerns in terms of generalizability. Future research could immensely enrich our findings by extending the focus of analysis to both large and smaller subsidiaries, located in other host countries, as well as belonging to other high-tech sectors.

Second, we measure most of our variables through the use of patents and patent citations. As literature has widely documented, the use of patent citation data to investigate knowledge flows encompasses some potential limitations. First, patents represent by definition the codified part of technology and do not allow capturing the transfer of tacit knowledge. However, this problem is partially mitigated by the fact that codified knowledge and tacit knowledge have been found to be correlated and complementary (Mowery, Oxley, \& Silverman, 1996). An additional issue deals with examiner-added citations: in fact, not all citations contained in the patent document are spontaneously indicated by the inventor. Notwithstanding this limitation, empirical analysis of spillovers has long recognized the effectiveness of the citation measure (Jaffe et al., 1993; Fogarty, Jaffe \& Trajtenberg, 2000; Branstetter, 2006), and leaves rather confident regarding its general significance. Finally, much knowledge creation and protection does not result in patent citations. For instance, knowledge-related activities such as cross-licensing, technology transfer, and hiring of key personnel do not in general find adequate reflection in patent citations. We recognize that these activities in general are important to subsidiaries' knowledge creation and protection. In future studies, looking at a more mixed set of subsidiaries and industries, we propose the employment of a survey instrument to incorporate indicators of broader knowledge creation and protection behaviors. Yet, in the particular industry studied here, semiconductors, the incentive for patenting is very strong, which implies a high likelihood that a large part of knowledge movements within and outside the firm are traced by patent citations (Song et al., 2003). As suggested by previous literature, the majority of firms in the semiconductor sector - regardless of their country origin own a substantial portfolio of US patents reflecting its innovative processes (Almeida \& Kogut, 1999; Almeida \& Phene, 2004; Lahiri, 2010; Phene \& Almeida, 2008). This is why, despite the limitations associated with the use of patent citations data, they have been increasingly used in 
management research to infer both the organizational and the technological influences and consequences of a particular invention, and thus track knowledge flows (Song et al., 2003). In sum, we recognize that analyzing the information stemming from patent documents is not the most accurate way to infer firms' strategic behaviors. However, this approach is not new to the empirical research on subsidiary knowledge management (Almeida \& Phene, 2004; Phene \& Almeida, 2008; Anand, 2011).

Finally, our study offers only a description of the link between the patterns of local knowledge outflows and the subsidiary-level antecedents considered. We propose some conclusions regarding mechanisms of reciprocity that may contribute in explaining the effect of subsidiaries' external focus in knowledge sourcing on the local knowledge outflows, as well as regarding the protective attitudes that might drive subsidiaries with high knowledge value to limit local knowledge diffusion. We suggest that the results of our empirical analysis may be interpreted in the light of the dynamics proposed in our conceptual model. However, we are not able to indicate the actual arrangements subsidiaries use to loosen or restrict the flow of their knowledge in the host-region. Similarly, our data do not allow measuring the trust between foreign and local counterparts, which is the basis of how social networks evolve and are used for objectives of knowledge creation/protection. In future studies, we plan to survey managers in order to measure the influence of trust on the knowledge-based relationships between local and foreign firms, as well as to gather direct data on the concrete measures subsidiaries carry out in order to optimize the interaction with the local knowledge network. This will help complementing our results.

Overall, while we were able to show that the outcomes - in terms of local knowledge outflows - of the interaction between an external focus in knowledge sourcing and a high knowledge value are in line with our expectations, we were limited in our capability, in the same way as previous scholars have been (e.g., Almeida \& Phene, 2004; Ahuja \& Katila, 2004), to isolate the process behind this relationship. Despite this limitation, we believe we've made a first step towards understanding the impact of subsidiaries knowledge strategies on local knowledge spillovers. 


\subsection{Practical Implications}

In terms of implications, this paper encompasses important insights for managers of both the subsidiaries and the local firms. Regarding the subsidiaries, most of prior research has looked at the phenomenon of knowledge outflows as a danger for firms, whose assets could be appropriated by competitors, thus losing their competitive value (Shaver \& Flyer, 2000; Alcacer \& Chung, 2007). In this study, we suggest how subsidiaries' managers may use their knowledge as "bargaining chips" in the relationships with the local partners, thus working "on the social side of the exchange calculus" (Kachra \& White, 2008; p. 441). In this case, allowing for the occurrence of knowledge outflows within the host location is just another competitive tool subsidiaries can use to gain access to the local knowledge network, thus acquiring the complementary resources they need to evolve. Of course, such strategy might become too dangerous in situations when the subsidiary knowledge value is very high. In these cases, subsidiaries' managers should rethink the decision to adopt reciprocity behaviors to tap into the local knowledge network. At the same time, they should invest more in the protection of their own knowledge resources, since they often constitute the real competitive asset that distinguishes them from local competitors.

Local firms' managers, on the other hand, should be aware that subsidiaries' "cooperative" behavior not necessarily signals a stable approach to the local knowledge network. Subsidiaries reciprocate to knowledge exchanges when this choice is consistent with the pursuit of their knowledge imperatives and with their need for knowledge creation, but they may turn to more opportunistic attitudes when sharing their resources within the local knowledge network implies a too high strategic loss.

The analysis also provides a major policy implication. In fact, when designing FDI-attraction strategies, policy makers should be aware that: (1) MNCs will likely share their knowledge with local firms mainly if they expect to gain something in return; (2) the most advanced subsidiaries, which own highly valuable knowledge and superior technology, are the ones contributing less to the local knowledge network, since they are likely to implement the strictest protection strategies to 
avoid external appropriation of their competitive assets. In conclusion, governments that aim to incentivize the localization of FDI in their countries should account for the possibility that the most technologically advanced subsidiaries might not be the best targets to attract, when aiming at fostering local firms' acquisition of MNCs' knowledge. 


\section{REFERENCES}

Ahuja, G., \& Katila, R. (2004). Where do resources come from? The role of idiosyncratic situations. Strategic Management Journal. 25, 887-907.

Aitken, L. S., \& West, S. G. (1991). Multiple regression: Testing and interpreting interactions. Newbury Park, CA: Sage.

Alcacer, J. \& Chung, W. (2007). Location strategies and knowledge spillovers. Management Science, 53(5): 760-776.

Almeida, P. (1996). Knowledge sourcing by foreign multinationals: patent citation analysis in the U.S. semiconductor industry. Strategic Management Journal, 17 (Winter Special Issue), 155-165.

Almeida, P., \& B. Kogut. (1999) Localization of Knowledge and the Mobility of Engineers in Regional

Networks. Management Science, 45:905-918.

Almeida, P. \& Phene, A. (2004). Subsidiaries and knowledge creation: the influence of the MNC and host country on innovation. Strategic Management Journal, 25: 847-864.

Anand, J. (2011). Permeability to inter and intra-firm knowledge flows: The role of coordination and hierarchy in MNEs. Global Strategy Journal, 3-4: 283-300..

Andersson, U., Forsgren, M., \& Holm, U. (2002). The strategic impact of external networks - Subsidiary performance and competence development in the multinational corporation. Strategic Management Journal 23, 979-996.

- (2007). Balancing subsidiary influence in the federative MNC - A business network perspective. Journal of International Business Studies 38, 802-818.

Andrews, K. M., B. L. Delahay. 2000. Influences on knowledge processes in organizational learning: The psychosocial filter. Journal of Management Studies, 37 797-810.

Arikan, A.T. (2009). Inter-firm knowledge exchanges and the knowledge creation capability of clusters. Academy of Management Review 34, 658-676.

Barney, J. (1991). Firm resources and sustained competitive advantage. Journal of Management 17, 99-120.

Bartlett, C. A., \& Ghoshal, S. (1989). Managing across boarders: the transnational solution. Boston: Harvard Business School Press.

Birkinshaw, J. (1997). Entrepreneurship in multinational corporations: the characteristics of subsidiary initiatives, Strategic Management Journal, Vol. 18:3 p 207-229. 
Birkinshaw, J., \& Hood, N. (1998). Multinational subsidiary development: Capability evolution and charter change in foreign-owned subsidiary companies. Academy of Management Review 23, 773-795.

Blomstrom, M. (1986). Foreign investment and productive efficiency: the case of Mexico. Journal of Industrial Economics, 35(1): 97-110.

Branstetter, L. (2006). Is foreign direct investment a channel of knowledge spillovers? Evidence for Japan's FDI in the United States. Journal of International Economics, 68: 325.344.

Buckley, P.J. \& Casson, M. (1976). The future of multinational corporations. London: Macmillan.

Cantwell, J. (1989). Technological Innovation and Multinational Corporations. Basil Blackwell: Oxford.

Cantwell, J., (1995). The Globalisation of Technology: What Remains of the Product Cycle Model? Cambridge Journal of Economics, Oxford University Press, vol. 19(1), pages 155-74, February.

Cantwell, J. \& Mudambi, R. (2005). MNE competence-creating subsidiary mandates. Strategic Management Journal, 26: 1109-1128.

Cantwell, J. \& Janne, O. (1999). Technological globalization and innovative centers: the role of corporate technological leadership and locational hierarchy. Research Policy 28(2-3): 119-144.

Caves, R.E. (1974). Multinational firms, competition and productivity in host-country markets. Economica, 41(162): 176-193.

Chesbrough, H.W. (2004). Managing Open Innovation. Research Technology Management. Vol. JanuaryFebruary 2004. p. 23-26.

Chow, C.W., Deng, F.J., and Ho, J.L. (2000). The openness of knowledge sharing within organizations: A comparative study of the United States and the People's Republic of China. Journal of Management Accounting Research, 12, 65-95.

Chung, W. (2001). Identifying technology transfer in foreign direct investment: influence of industry conditions and investing firm motives. Journal of International Business Studies, 32(2): 211-229.

Chung, W. \& Alcacer, J. (2002). Knowledge seeking and location choice of foreign direct investment in the United States. Management Science, 48(12): 1534-1554.

Coleman, J. S. (1988). Social capital in the creation of human capital. American Journal of Sociology, 94(Supplement): S95-S120.

Crespo, N. \& Fontoura M.P. (2007). Determinant Factors of FDI Spillovers-What Do We Really Know? World Development, 35(3): pp. 410-425. 
Criscuolo, P., Narula, R. \& Verspagen, B. (2002). The relative importance of home and host innovation systems in the internationalisation of MNE R\&D: a patent citation analysis, MERIT-Infonomics Research Memorandum series n. 026.

De Faria, P., \& Sofka, W. (2010). Knowledge protection strategies of multinational firms - A cross-country comparison. Research Policy 39, 956-968.

Driffield, N. \& Love, H.J. (2007). Linking FDI motivation and host economy productivity effects: conceptual and empirical analysis. Journal of International Business Studies, 38: 460-473.

Driffield, N., Love, J.H., \& Menghinello, S. (2010). The multinational enterprise as a source of international knowledge flows: direct evidence from Italy. Journal of International Business Studies 41, 350-359.

Driffield, N., Munday, M. \& Roberts, A. (2002). Foreign Direct Investment, transactional linkages, and the performance of the domestic sector. International Journal of the Economics of Business, 9(3): 335-351.

Dunning, J. H. (1981). Explaining the international direct investment position of countries: Towards a dynamic or developmental approach, Weltwirtschaftliches Archiv, vol. 122, pp. 667- 677.

Dyer, J. H., \& Hatch, N. W. (2006). Relation-specific capabilitiesand barriers to knowledge transfers: Creating advantage through network relationships. Strategic Management Journal, 27(8): 701-719.

Dyer, J., \& Singh, H. (2000). Learning and protection of proprietary assets in strategic alliances: Building relational capital. Strategic Management Journal 21, 217-237.

Eapen, A. (2012). Social Structure and Technology Spillovers from Foreign to Domestic Firms, Journal of International Business Studies, 43, 244-263.

Ensign, S; Birkinshaw, J., \& Frost, T. (2000). R\&D centres of excellence in Canada, in Pedersen T. and Holm U. eds., Centres of excellence in multinational enterprises, Macmillan.

Feinberg, S.E. \& Majumdar, S.K. (2001). Technology spillovers from foreign direct investment in the Indian pharmaceutical industry. Journal of International Business Studies, 32(3): 421-437.

Findlay, R. (1978). Relative Backwardness, Direct Foreign Investment, and the Transfer of Technology: A Simple Dynamic Model. Quarterly Journal of Economics, 92: 1-16.

Fogarty, M., Jaffe, A. \& Trajtenberg M. (2000). The meaning of patent citations: Report of the NBER/CaseWestern Reserve Survey of Patentees. Working Paper.

Frost, T.S. (2001). The geographic sources of foreign subsidiaries' innovations. Strategic Management Journal, 22, pp. 101-123. 
Frost, T., Birkinshaw, J. \& Ensign, P.C., (2002). Centers of excellence in multinational corporations, Strategic Management Journal, Vol. 23:11 p 997- 1015.

Ghauri, P.N. \& Buckley, P.J. (2006). Globalization, multinational enterprises and world poverty, in: Subhab, C.J. \& Sushil V. (Eds), Multinational Corporations and Global Poverty Reduction (pp. 204-232). Cheltenham, UK: Edward Elgar Publishing.

Glass, A. \& Saggi, K. (1998). International Technology Transfer and the Technology Gap. Journal of Development Economics, 55: 369-398.

Giroud, A. \& Scott-Kennel, J. (2009). MNE linkages in international business: A framework for analysis. International Business Review, 18(6): 555-566.

Gittelman, M. \& Kogut, B. (2003). Does good science lead to valuable knowledge? Biotechnology firms and the evolutionary logic of citations patterns. Management Science, 49(4):366-382.

Görg, H. \& Greenaway D. (2003). Much ado about nothing? Do domestic firms really benefit from foreign direct investment? World Bank Research Observer, 19: 171-197.

Gouldner, A.W. (1960). The norm of reciprocity: A prelimenary statement. American Sociological Review $25,161-78$.

Grant, R.M. (1996). Toward a Knowledge-Based Theory of the Firm, Strategic Management Journal (17), Winter Special Issue, pp. 109-122.

Gulati, R. (1995). Social structure and alliance formation patterns: a longitudinal analysis. Administrative Science Quarterly 40, 619-652.

- (1998). Alliances and networks. Strategic Management Journal, 19(4): 293-317.

Johanson, J., \& Mattsson, L.G., (1992), Network Positions and Strategic Actions-An Analytical Framework, in B. Axelsson and G. Easton (eds), Industrial Networks: A New View of Reality, London, Routledge.

Håkansson, H. \& Snehota I. (1989). No Business is an Island: the Network Concept of Business Strategy, Scandinavian Journal of Management, Vo1.4(3).

Hall, B. H., A. B. Jaffe, \& M. Trajtenberg (2001). The NBER Patent Citation Data File: Lessons, Insights and Methodological Tools. NBER Working Paper 8498.

Hall, B.H., Jaffe, A.B. \& Trajtenberg, M. (2005). Market value and patent citations. Rand Journal of Economics, 36(1): 16-38.

Haskel, J.E., Pereira, S.C. \& Slaughter, M.J. (2007). Does inward foreign direct investment boost the productivity of domestic firms? The review of economics and statistics, 89(3): 482-496. 
Hausman, J., Hall, B., \& Griliches, Z. (1984). Econometric models for count data with an application to the patents-R\&D relationship. Econometrica 52 (4), 909-938.

Hedlund, G. (1994). A model of knowledge management and the N-form corporation. Strategic Management Journal 15, 73-90.

Holm, U. \& Pedersen, T. (2000). The Emergence and Impact of MNC Centres of Excellence: A Subsidiary Perspective, MacMillan, London.

Ingram, P., \& Lifschitz, A. (2006). Kinship in the shadow of the corporation: The interbuilder network in Clyde river shipbuilding, 1711-1990. American Sociological Review, 71(2): 334-352.

Lahiri, N. (2010). Geographic Dispersion of R\&D Units: How Does it Help Innovation? Academy of Management Journal. 2010. 53 (5).

Laursen, K. \& Salter, A. (2006). Open for Innovation: The role of openness in explaining innovative performance among UK manufacturing firms, Strategic Management Journal, 131-150.

Lundvall, B.A. (1992). National Systems of Innovation: Towards a Theory of Innovation and Interactive Learning. Pinter, London.

Jaffe, A. B. (1986). Technological Opportunity and Spillovers of R\&D: Evidence from Firms' Patents, Profits, and Market Value, American Economic Review, vol. 76(5), pages 984-1001.

Jaffe, A.B., Trajtenberg, M. \& Hendersen, R. (1993). Geographic localization of knowledge spillovers as evidenced by patent citations. The Quarterly Journal of Economics, 108: 577-598.

Jaffe, A.B., Trajtenberg, M. \& Fogarty, M.S. (2000). The meaning of patent citations: report on the NBER/Case-Western Reserve Survey of patentees. NBER Working Paper, No. 7631.

Kachra, A. \& White, R. (2008). Know-how transfer: the role of social, economic/competitive, and firm boundary factors. Strategic Management Journal, 29: 425-445.

Kogut, B. \& Zander, U. (1993). Knowledge of the firm and the evolutionary theory of the multinational corporation. Journal of International Business Studies, 24: 61-90.

Kokko, A. (1994). Technology, market characteristics, and spillovers. Journal of Development Economics, 43: 279-293.

Kokko, A., Tasini, R., \& Zejan M. (1996). Local technological capability and productivity spillover from FDI in the Uruguayan manufacturing sector, Journal of Development Studies, 32, 602-611. 
Kotabe, M., Martin, X., \& Domoto, H. (2003). Gaining from vertical partnerships: Knowledge transfer, relationship dura- tion, and supplier performance improvement in the US and Japanese automotive industries. Strategic Management Journal, 24(4): 293-316.

Marin, A., \& Bell, M. (2006) Technology spillovers from Foreign Direct Investment; the active role of MNC subsidiaries in Argentina in the 1990. Journal of Development Studies, 42(4), p. 678-697. .

Marshall, A. (1920). Principles of Economics. Macmillan: London.

McEvily, B., \& Zaheer, A. (1999). Bridging ties: A source of firm heterogeneity in competitive capabilities. Strategic Management Journal, 20(12): 1133-1156.

Michailova, S. and Hutchings, K. (2006). National cultural influences on knowledge sharing: A comparison of China and Russia. Journal of Management Studies, 43 (3), 383-405.

Michailova, S. and Husted, K. (2003), Knowledge sharing in Russian companies with Western participation, Management International, Vol. 6 No. 2, pp. 19-28.

Mowery, D., Oxley, J., \& Silverman, B. (1996). Strategic Alliances and Interfirm Knowledge Transfers. Strategic Management Journal 17(Winter96 special issue): 77-91

Mudambi, R. (2002). Knowledge management in multinational firms. Journal of International Management, 8:1-9.

Mudambi, R., \& Navarra, P. (2004). Is knowledge power? Knowledge flows, subsidiary power and rentseeking within MNCs. Journal of International Business Studies 35, 385-404.

Narula, R. \& Dunning, J. (2000), Industrial Development, Globalisation and Multinational Enterprises: New Realities for Developing Countries. Oxford Development Studies, 28, 141-167.

Neter, J., Wasserman, W., \& Kutner, M. (1983) Applied Linear Regression Models, Richard D. Irwin Inc., Homewood, IL.

Hansen, M. T. (1999). The search-transfer problem: The role of weak ties in sharing knowledge across organization subunits. Administrative Science Quarterly, 44(1): 82-111.

Håkansson, L., \& Nobel, R. (2001). Organizational characteristics and reverse technology transfer. Management International Review 41, 395-420. 
Javorcik B.S. (2004). Does foreign direct investment increase the productivity of domestic firms? In search of spillovers through backward linkages. American Economic Review, 94, 605-627.

Patel, P, \& Pavitt, K. (1991). Large firms in production of world's technology. Journal of International Business Studies 22(1): 1-22.

Perri, A., Andersson, U., Nell, P.C., \& Santangelo, G.D. (2013), Balancing the Trade-Off between Learning Prospects and Spillover Risks: MNC Subsidiaries' Vertical Linkage Patterns in Developed Countries, Journal of World Business, forthcoming.

Peteraf, M., \& Shanley, M. (1997). Getting to know you: A theory of strategic group identity. Strategic Management Journal, 18(S1): 165-186.

Phene, A. \& Almeida, P. (2008). Innovation in multinational subsidiaries: the role of knowledge assimilation and subsidiary capabilities. Journal of International Business Studies, 39: 901-919.

Polidoro Jr., F., Ahuja, G., \& Mitchell, W. (2011). When the social structure overshadows competitive incentives: The effects of network embeddedness on joint venture dissolution. Academy of Management Journal, 54(1): 203-223.

Porter, M. (1990). The Competitive Advantage of Nations. Free Press: New York.

Reagans, R., \& McEvily, B. (2003). Network structure and knowledge transfer: The effects of cohesion and range. Administrative Science Quarterly, 48(2): 240-267.

Rodriguez-Clare, A., (1996). Multinationals, linkages, and economic development. American Economic Review 86, 852-873.

Rogers, E., \& Larsen, J. (1984). Silicon Valley Fever. Basic Books: New York.

Sako, M. (1996). Suppliers' associations in the Japanese automobile industry: Collective action for technology diffusion. Cambridge Journal of Economics, 20(6): 651-671.

Saxenian, A., (1994). Regional Advantage: Culture and Competition in Silicon Valley and Route 128. Harvard University Press, Cambridge, MA.

Shaver, J.M. \& Flyer, F. (2000). Agglomeration economies, firm heterogeneity, and foreign direct investment in the United States. Strategic Management Journal, 21: 1175-1193.

Schrader, S. (1991). Informal technology transfer between firms: Cooperation through information trading. Research Policy, 20(2): 153-170. 
Singh, J. (2005). Collaborative networks as determinants of knowledge diffusion patterns. Management Science, 51(5): 756-770.

- (2007). Asymmetry of knowledge spillovers between MNCs and host country firms. Journal of International Business Studies, 38: 764-786.

- (2008). Distributed R\&D, Cross-Regional Knowledge Integration and Quality of Innovative Output. Research Policy, 37(1), pp. 77-96

Song, J., Almeida, P. \& Wu, G. (2003). Learning-by-hiring: when is mobility more likely to facilitate interfirm knowledge transfer? Management Science, 49(4): 351-365.

Spencer, W.J. (2008). The impact of multinational enterprise strategy on indigenous enterprises: horizontal spillovers and crowding otu in developing countries. Academy of Management Journal, 33(2): 341-361.

Tallman, S. \& Phene, A. (2007). Leveraging Knowledge Across Geographical Boundaries. Organization Science, 18(2), 252-260.

Teece, D. (1977). Technology transfer by multinational firms: the resource costs of transferring technological know-how. Economic Journal, 87: 242-261.

Trajtenberg, M. (1990), A penny for your quotes: Patent citations and the value of innovations, Rand Journal of Economis, 172-187.

Uzzi, B. (1996). The sources and consequences of embeddedness for the economic performance of organizations. American Sociological Review, 61, 674-698.

- (1997). Social structure and competition in interfirm networks. The paradox of embeddedness. Administrative Science Quarterly, 42(1): 35-67.

Veugelers, R. (1997). Interval R\&D expenditures and external technology sourcing. Research Policy, 26(3), 303-315.

von Hippel, E. (1987). Cooperation between rivals: Informal know-how trading. Research Policy, 16(6): 291-302.

- (1988), The Sources of Innovation. Oxford University Press: New York.

Wang, J.Y. \& Blomstrom, M. (1992). Foreign Investment and Technology Transfer: A Simple Model, 
European Economic Review, 36, 137-155.

Williamson, O. (1993). Calculativeness, trust and economic organisation, Journal of Law and Economics, $36: 453-486$.

Zaheer, A., B. McEvily,V. Perrone. (1998). Exploringthe effects of interorganizational and interpersonal trust on performance. Organization Science, 9 141-159

Zhao, M. (2006). Conducting R\&D in countries with weak intellectual property rights protection. Management Science, 52(8): 1185-1199. 
Table 1. Correlation matrix

\begin{tabular}{|c|c|c|c|c|c|c|c|c|c|c|c|c|}
\hline & 1 & 2 & 3 & 4 & 5 & 6 & 7 & 8 & 9 & 10 & 11 & 12 \\
\hline 1 Local_Know_Flows & 1.000 & & & & & & & & & & & \\
\hline 2 External Focus & 0.633 & 1.000 & & & & & & & & & & \\
\hline 3 Know_Value & 0.208 & -0.001 & 1.000 & & & & & & & & & \\
\hline 4 HQ_Know_Stock & 0.028 & -0.008 & 0.236 & 1.000 & & & & & & & & \\
\hline 5 Ptf_Size & 0.544 & 0.641 & 0.108 & 0.014 & 1.000 & & & & & & & \\
\hline 6 R\&D_Int & 0.067 & 0.166 & 0.026 & 0.140 & 0.333 & 1.000 & & & & & & \\
\hline 7 Sub_Age & 0.454 & 0.288 & 0.653 & 0.298 & 0.390 & 0.232 & 1.000 & & & & & \\
\hline 8 Team_Size & -0.037 & -0.006 & 0.025 & 0.325 & -0.063 & 0.009 & 0.081 & 1.000 & & & & \\
\hline 9 Ptf_Age & -0.039 & 0.029 & -0.335 & -0.144 & -0.105 & -0.074 & -0.348 & -0.047 & 1.000 & & & \\
\hline 10 Cluster_Importance & 0.232 & 0.152 & 0.384 & -0.010 & -0.069 & -0.004 & 0.255 & -0.044 & -0.051 & 1.000 & & \\
\hline 11 Tech_Proximity & 0.183 & 0.195 & 0.292 & 0.164 & 0.150 & 0.261 & 0.372 & 0.061 & -0.111 & 0.149 & 1.000 & \\
\hline 12 Home_Region & 0.179 & 0.122 & -0.102 & 0.074 & 0.027 & 0.161 & 0.142 & 0.039 & 0.056 & 0.004 & 0.209 & 1.000 \\
\hline Mean & 4.227 & 3.079 & 3.337 & 1420.483 & 16.306 & 0.070 & 11.312 & 0.260 & 0.473 & 135.950 & 0.834 & 0.103 \\
\hline Std. Dev. & 8.468 & 5.869 & 2.649 & 746.900 & 38.481 & 0.040 & 6.568 & 0.752 & 0.618 & 131.427 & 0.253 & 0.305 \\
\hline
\end{tabular}


Table 2. Subsidiary Knowledge Outflows: Negative Binomial Regressions with Random Effects

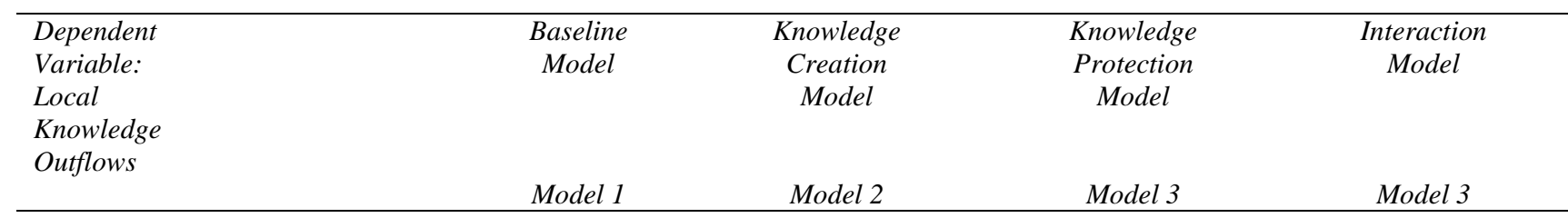

Independent Variables

Hp. 3: Ext_Focus_Value

Hp. 2: Know_Value

Hp. 1: External_Focus

$0.028 * * *$

$0.026 * * *$

(4.00)

Controls

\begin{tabular}{|c|c|c|c|c|}
\hline HQ_Know_Stock & $\begin{array}{l}0.000 \\
(1.19)\end{array}$ & $\begin{array}{l}0.000 \\
(0.57)\end{array}$ & $\begin{array}{l}0.000 \\
(1.01)\end{array}$ & $\begin{array}{l}0.000 \\
(1.34)\end{array}$ \\
\hline Cluster_Importance & $\begin{array}{l}-0.001 \\
(-1.03)\end{array}$ & $\begin{array}{l}-0.001 \\
(-0.77)\end{array}$ & $\begin{array}{l}-0.001 \\
(-0.53)\end{array}$ & $\begin{array}{l}-0.001 \\
(-0.77)\end{array}$ \\
\hline Sub_Age & $\begin{array}{l}-0.046 \\
(-1.03)\end{array}$ & $\begin{array}{l}-0.040 \\
(-1.24)\end{array}$ & $\begin{array}{l}-0.010 \\
(-0.26)\end{array}$ & $\begin{array}{l}-0.043 \\
(-1.16)\end{array}$ \\
\hline Ptf_Size & $\begin{array}{c}0.030 * * * \\
(4.07)\end{array}$ & $\begin{array}{c}0.023 * * * \\
(3.12)\end{array}$ & $\begin{array}{c}0.021 * * \\
(2.45)\end{array}$ & $\begin{array}{c}0.028 * * * \\
(3.53)\end{array}$ \\
\hline Ptf_Age & $\begin{array}{l}0.206 \\
(1.48)\end{array}$ & $\begin{array}{l}0.229 * \\
(1.75)\end{array}$ & $\begin{array}{l}0.147 \\
(1.13)\end{array}$ & $\begin{array}{l}0.074 \\
(0.57)\end{array}$ \\
\hline R\&D_Int & $\begin{array}{l}-1.673 \\
(-0.85)\end{array}$ & $\begin{array}{l}-1.569 \\
(-0.86)\end{array}$ & $\begin{array}{l}-2.148 \\
(-1.15)\end{array}$ & $\begin{array}{l}-2.417 \\
(-1.41)\end{array}$ \\
\hline Team_Size & $\begin{array}{l}-0.049 \\
(-0.43)\end{array}$ & $\begin{array}{l}-0.036 \\
(-0.32)\end{array}$ & $\begin{array}{l}-0.090 \\
(-0.78)\end{array}$ & $\begin{array}{l}-0.089 \\
(-0.79)\end{array}$ \\
\hline Tech_Proximity & $\begin{array}{l}0.793 \\
(0.87)\end{array}$ & $\begin{array}{l}0.752 \\
(0.90)\end{array}$ & $\begin{array}{l}1.654^{*} \\
(1.66)\end{array}$ & $\begin{array}{l}0.840 \\
(0.89)\end{array}$ \\
\hline Home_Region & $\begin{array}{l}0.788^{*} \\
(1.80)\end{array}$ & $\begin{array}{l}0.508 \\
(1.32)\end{array}$ & $\begin{array}{l}0.138 \\
(0.25)\end{array}$ & $\begin{array}{l}0.394 \\
(0.83)\end{array}$ \\
\hline Const & $\begin{array}{c}-4.613 * * * \\
(-3.09)\end{array}$ & $\begin{array}{c}-4.410 * * * \\
(-3.06)\end{array}$ & $\begin{array}{c}-6.162 * * * \\
(-3.80)\end{array}$ & $\begin{array}{c}-4.987 * * * \\
(-3.21)\end{array}$ \\
\hline Statistic & $196.54 * * *$ & $234.11 * * *$ & $206.15^{* * *}$ & $243.14 * * *$ \\
\hline & 299 & 299 & 299 & 299 \\
\hline
\end{tabular}

1) Standard errors in parentheses. 
2) $* \mathrm{p}<0.1, * * \mathrm{p}<0.05, * * * \mathrm{p}<0.01$.

3) All models include year dummies and MSA dummies. 
